\title{
FUNGSI-FUNGSI PENDIDIKAN DALAM HIDUP DAN KEHIDUPAN MANUSIA
}

\author{
Oleh : Muh. Judrah ${ }^{1}$
}

$* * *$

\begin{abstract}
Abstrak
Fungsi pendidikan Islam dalam kaitannya dengan hidup dan kehidupan manusia, dapat ditulusuri dari hakikat manusia sejak lahirnya yang memiliki fitrah, yakni potensi pembawaan yang menyebabkan dirinya harus terlibat dalam dunia pendidikan. Dalam pada itulah maka manusia homo aducandum (makhluk yang dapat didik) dan homo education (mkhluk pendidik). Dengan demikian, fungsi pendidikan Islam secara totalitas adalah, untuk membangun manusia yang mampu membangun dunia dengan segala dimensinya, sesuai dengan komitemen imannya terhadap Allah swt. Selain itu, fungsi pendidikan islam dalam membina manusia dengan segala aspeknya, terutama menyangkut dimensi keimanan dan ketaqwaan harus benr-benar berwujud. Atas dasar itu, maka dalam pandangan penulis bahwa pendidikan islam secara fungsional. Dengan cara seperti ini, merupakan konsekuensi penguatan komitmen iman bagi peserta didik terhadap Allh swt. Yang kemudian dimanifestasikan dalam ketaatan beribadah kepada-Nya.
\end{abstract}

Kata Kunci : Fungsi-fungsi pendidikan, kehidupan manusia

\section{PENDAHULUAN}

\section{A. Latar Belakang Masalah}

$\mathrm{D}$ alam sejarah pertumbuhan masyarakat pendidikan senantiasa menjadi perhatian utama dalam rangka memajukan kehidupan generasi sejalan dengan tuntutan kemajuan perkembangan masyarakat yang mengitarinya. ${ }^{2}$ Pendidikan tersebut di tujukan bukan hanya pada pembinaan keterampilan melainkan kepada pengembangan kemampuan-kemampuan teoritis

\footnotetext{
${ }^{1}$ Dosen Tetap pada STAI Muhammadiyah SInjai

${ }^{2}$ HM. Arifin, Ilmu pendidikan Islam, Suatu tinjauan Teoritis dan Praktis Ber-dasarkan pendekatan. Interdisipliner. (Jakarta: Bumi aksara. 1997). h. 4
} 


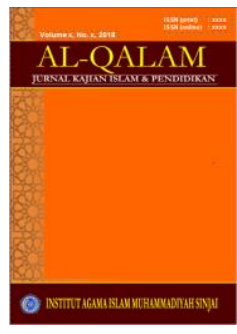

dan praktis yang berorientasi pada hubungan pada tuhan dan manusia atau masyarakat, serta alam sekitarnya. ${ }^{3}$ Dari tiga orientasi itulah sehingga manusia mengembangkan proses pertumbuhan kebudayaannya. Untuk sampai kepada kebutuhan tersebut di perlukan implementasi fungsi pendidikan yang dapat mengembangkan kehidupan manusia yang lebih baik.

Badan pendidikan dunia ( UNESCO) telah merekomendasikan empat pilar fungsi pendidikan yaitu belajar untuk mengetahui atau learning to Know, belajar untuk bisa bekerja atau learning to do, belajar untuk dapat berakktualisaasi diri atau learning to life, serta belajar untuk bisa hidup bersama dengan orang lain atau learning to life together. ${ }^{4}$ Yang terakhir bisa diistilahat bahwa belajar adalah untuk hidup dan kehidupan manusia.

Lebih lanjut pakar pendidikan seperti Abu Ahmadi mengumukakan bahwa masalah pendidikan adalah masalah yang sangat penting dalam kehidupan manusia, bahkan masalah pendidikan sama sekali tidak dapat di pisahkan dengan kehidupan individu, kehidupan keluarga maupun dalam kehidupan masyarakat. ${ }^{5}$ Dalam kehoidupan individu dan keluarga diperlukan konsep lingkungan pendidikan yang di sebut pendidikan informal yang mapan, demikian pula di dalamkehidupan masyarakat diperlukan pendidikan non-formal, sebagaimana diperlukannya pendidikan di sekolah dengan istilah lingkungan pendidikan formal.

Ketiga lingkungan yang disebutkan di atas, merupakan satu sistem yang dapat memungkinkan terjadinya proses pendidikan dengan baik dan mencapai cita-cita yang diinginkan, ${ }^{6}$ yang karena itu dengan mengfungsikannya dengan baik , maka pendidikan akan berfungsi untuk hidup dan kehidupan manusia. Implementasi terhadap fungsi tersebut, menjadi penekanan dalam konsep pendidikan Islam. Itulah sebabnya sehingga manusia sejak lahirnya memiliki fitrah, yakni potensi pembawaan yang menyebabkan dirinya harus terlibat dalam dunia pendidikan. Dalam pada itulah maka manusia disebut sebagai Homo educandum (makhluk yang dapat didik ) dan homo edication (makhluk pendidikan). Implementasi dari aspek kefungsian ini menarik untuk dikaji lebih lanjut.s

\footnotetext{
${ }^{3}$ Ibid. H.5

${ }^{4}$ Lihat Irsyad Duali, pembaharuan Kembali Pendidikan Islam( Jakarta : Karsa Utama Mandiri. 1998, h. 18

${ }^{5}$ Abu Ahmadi, Ilmu pendidikan (Cet.I : Jakarta Aneka Cipta, 1991). H.98

${ }^{6}$ H.M. Arifin,op., cit h.83
} 


\section{B. Rumusan Masalah}

Berdasarkan uraian yang telah dikemukakan, maka sebagai masalah pokok yang hendak dikaji adalah bagaimana fungsi-fungsi pendidikan Islam dalam hidup dan kehidupan manusia?

Sebagai sub masalahnya adalah:

1. Bagaimana hakikat manusia sebagai obyek dan subyek pendidikan perspektif Islam?

2. Bagaimana fungsi pendidikan Islam bagi manusia dalam hidup dan kehidupan?

\section{PEMBAHASAN}

\section{A. Hakikat Manusia sebagai obyek dan subyek pendidikan perspektif Islam}

Ibn Maskawaih menyatakan bahwa manusia pada hakikatnya tersusun atas jasad (materi), dan roh (non materi) yang menyebabkan ia hidup (hayat). Bila manusia mendapatkan didikan dengan baik, akan menembuhkan sikap mental atau jiwa yang menjadikan dirinya sempurna. Kesempurnaan yang dicari oleh manusia ialah kebajikan dalam bentuk ilmu pengetahuan dan tidak tunduk pada hawa nafsu serta keberanian dan keadilan. ${ }^{7}$ Dari sini dipahami bahwa tujuan sekaligus fungsi pendidikan islam mengandung makna tentang perubahan yang diinginkan dan diusahakan oleh manusia untuk menjadikan dirinya lebih sempurna melalui pencarian ilmu pengetahuan dalam proses pendidikan.

Proses pendidikan bagi manusia berdasarkan naluri fitrahnya yang bersumber dari fitrahnya sendiri. Term fitrahnya atau al-fithrah dan derivasi-nya disebut sebanyak 20 kali dalam alquran. ${ }^{8}$ Dari ayat-ayat tersebut, makna fitrah dikelompok-kan menjadi dua. Pertama, fitrah berarti al-syaqq (pecah/belah) yang ditunjukan pada obyek langit belaka. ${ }^{9}$ Kedua, fitrah berarti al-Khilqah (penciptaan) yang obyeknya manusia. ${ }^{10}$ selanjudnya bila pembicaraan di tunjukan

${ }^{7}$ Lihat Ibn Maskawaih, tahzib a-Akhlak, diterjemahkan oleh Helmi Hidayat dengan Judul kesempurnaan Akhlak(Bandung: Mizan, 1994), h.41.

${ }^{8}$ Muhammad Fu'ad 'Abd. Al-Baqy, Al-Mu'jam al-Mufahras li Alfazh al-Qur'an (Bairut : Dar al-Fikr, 1982) H,. 663-664.

${ }^{9}$ Lihat Misalnya QS. Maryam (19):90;QA.al-Syura (42):11;QS. Al-Mulk (67): 3; QS.alMuzammil (73):18.

${ }^{10}$ Lihat Misalnya QA.Hud (11):51 dan QS.al-Rum (30):30. 
pada kaitan fitrah dengan kepribadian, praktis berfokus pada makna yang terakhir, yakni pencipta manusia. Adapun ayat sering kali dikutip ketika membahas tentang konsep fitrah dan asal kejadian manusia adalah QS. Al-Rum (30:30.

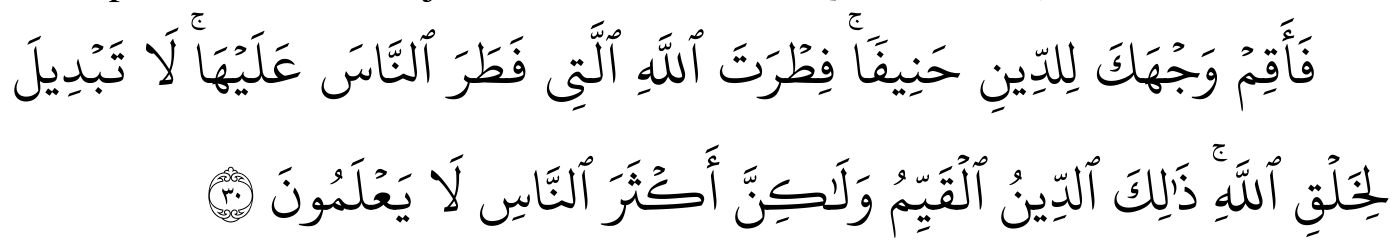

Terjemahanya:

Maka hadapkanlah wajahmu dengan lurus kepada agama (Alla); (tetaplah Atas ) fitrah allah yang telah menciptakan manusia menurut fitrah itu. Tidak ada perubahaan pada fitrah Allah.(itulah) Agama yang lurus ; tetapikebanyakan manusia tidak mengetahui. ${ }^{11}$

Al- Ashfahani menjelaskan bahwa (fitrahtallah) dalam ayat tersebut, mengandung interprestasi bahwa manusia di ciptakan oleh Allah mempunyai naluri beragama, yaitu agama tauhid yang hanif. ${ }^{12}$ Jadi dipahami bahwa konsep penciptaan manusia dikorelasikan dengan konsep agama, dan agama yang dimaksud tiada lain adalah islam yang di sebut dinullah ${ }^{13}$ (agama milik Allah ), dinullaq $^{14}$ (agama yang benar) dan dinulqayyim ${ }^{15}$ (agama yang tepat dan tegak ). Itu berarti bahwa agam islam, merupakan fitrah Allah atau asal kejadiannya sesuatu, ${ }^{16}$ termasuk asal kejadian manusia. Dari keterangan ini, dapat dipahami bahwa allah menciptakan manusia bersama dengan penciptaan fitrahnya.

Sebagaiman yang telah dijelaskan bahwa manusia terdiri dua unsur yakni fisik danpsikis, fisik merupakan aspek biologis dari struktur kepribadian. Unsure ini tercipta bukan dipersiapkan untuk membentuk tingkah laku sendiri, melainkan sebagi wadah atau tempat singgah fitrah islam, fitrah ketuhanan, atau fitrah ruhaniyah. Kedirian dan kesendirian fitrah fisik tidak akan mampu membentuk

11 Depertemen Agama RI,Al-Qur'an dan Terjemahanya (Jakarta: Proyek Pengadaan Kitab Suci al-Qur'an, 2002)., h. 645.

${ }^{12}$ Lihat al-Raghib al-Ashfahani, mufradat Alfazh al-Qur'an ( Cet. I; Bairut: Dar alSyamiyah, 1992), h. 640.

\footnotetext{
${ }^{13}$ Lihat QS.Ali Imran (3):83.

${ }^{14}$ Lihat QS.al-Shaf (61):9

${ }^{15}$ Lihat QS.al-Taubah (9):36.

${ }^{16}$ Lihat QS. Al-Rum (30):39.
} 
suatu tinggah laku batiniah. Kedirian fitarah jasmani bagaikan symbol lafaz yang tidak bermakna atau bagaikan lampu yang tidak menyala.

Abdul Mujid menjelaskan bahwa fitra fisik memiliki daya atau energy yang mengembangkan proses jasmaninya. Energy ini lazimnya disebut dengan daya hidup (al-hayat). Daya hidup kendatipun sifatnya abstrak tetapi ia belum mampu menggerakkan suatu tingkah laku. Suatu suatu tingkah laku terwujud apabila fitrah jasmani telah ditempati oleh ruhani. ${ }^{17}$ Konsep kepribadian islam semacam itu menyalahi persepsi "psikologis" iblis. Iblis mendugah bahwa subtansi dirinya lebih baik dari pada subtansi manusia. Ia tercipta dari api, sedangkan manusia tercipta dari tanah. Api menjadi bahan dasar penciptaan iblis baik naturnya dari pada tanah yang menjadi bahan dasar pencipta manusia.

Manusia dalam konsepsi Islam merupakan makhluk mulia yang memiliki struktur kompleks, meliputi fitrah jasmani, fitrah ruhani,. Fitrah ruhani lebih dahulu adanya dari pada fitrah jasmani. Kedua struktur itu sama-sama merupakan subtansi yang menyatu satu struktur subtantif, yaitu fitrah nafsani. Oleh sebab itu, pemahaman kepribadian manusia tidak hanya tertumpuh pada fitrah jasmani melainkan harus meliputi fitrah ruhani.

Potensi sitrah berupa agama islam pada diri manusia yang terbawa sejak lahirnya menyebabkannya selalu mencari yang dipandang sebagai relitas mutlak (ultimate reality), dengan cara mengekspresikannya dalam bentuk sikap inilah sehingga manusia juga disebut sebagai homo educandum (makhluk pendidikan ), karena pendidikan baginya adalah suatu keharusan guna mewujudkan kualitas dan integritas kepribadian yang utuh, yakni kepribadian muslimin.

Kepribadian manusia dari segi fitrahnya, telah mendapatkan perhatian dari kalangan pakar pendidikan dengan berbagai alirannya. Studi mereka lebih berfokus pada factor-faktor yang menentuk kepribadian. Terdapat tiga aliran besar yang masing-masing memiliki asumsi berbeda dalam melihat faktor- faktor yang membentuk kepribadian. Tiga aliran tersebut adalah nativisme, empirisme, dan konvergensi.

1. Aliran Nativisme

Nativisme berasal dari kata natus= lahir; nativis = pembawaan yang ajarnya memandang manusia (anak manusia) sejak lahir telah membawa sesuatu kekuatan yang di sebut potensi (dasar). ${ }^{18}$ Aliran nativisme ini,

17 Abdul Mujib, fitrah dan kepribadian Islam; sebuah pendekatan psikologis (Cet.I;Jakarta: Darul Falah,1999),h. 135.

${ }^{18}$ Lihat Sumardi Suryabrata, Psikologi Perkembangan (Yogyakarta: Rake Press, 1984), h.85. 
bertolak dari leibnitzia tradition yang menekankan kemamouan dalam diri setiap pribadi, sehingga faktor lingkungan termasuk foktor pendidikan, kurang berpengaruh terhadap kepribadian. Dengan kata lain bahwa aliran nativisme berpandangan segala sesuatunya ditentukan oleh foktor- faktor yang dibawa sejak lahir, jadi perkembangan individua itu semata- mata dimungkinkan dan ditentukan oleh dasar turunan, misalnya; kalau orang tuanya berkepribadian muslim, kemungkinan besar anaknya juga berkepribadian muslim.

Bagi nativisme, lingkungan sekitar tidak ada artinya sebab lingkungan tidak akan berdaya dalam mempengaruhi kepribadian seseorang. Penganut pandangan ini menyatakan bahwa kalau anak mempunyai pembawaan kepribadian jahat, dia akan menjadi jahat, sebaliknya kalau anak mempunyai pembawaan kepribadian yang baik, dia akan menjadi orang yang baik. Kepribadian buruk dan baik ini tidak dapat dirubah oleh kekuatan lingkungan. Berkenaan dengan inti ajaran aliran nativisme, dapat di pahami bahwa aliran ini bersifat passimisme, karena para penganutnya menunjukkan sifat pesimisme terhadap kemampuan manusia dalam mengembangkan kepribadiannya yang dibawa sejak lahir. Dengan kata lain, kepribadian anak seluruhnya ketentuan oleh hukum- hukum pewarisan.

2. Empirisme

Aliran empirisme, bertentangan dengan paham aliran nativisme. Empirisme (empiri artinya, pengalaman), dan disebut juga aliran environ mentalisme, yaitu suatu aliran yang menitikberatkan pandangan-Nya pada peranan lingkungan sebagai penyebab timbulnya kepribadian. ${ }^{19}$ Aliran ini tidak mengakui adanya pembawaan atau potensi kepribadian yang dibawah manusia sejak kelahirannya. Dengan kata lain bahwa anakmanusia itu lahir dalam keadaan pengertian anak bersih tidak membawa apa-apa. Karena itu, aliran ini berpandangan bahwa kepribadian seseorang besar pengaruhnya pada faktor lingkungan.

Asumsi psikologi yang mendasari aliran empirisme ini, adalah manusia lahir dalam keadaan netral, tidak memiliki pembawaan kepribadian. Ia bagaikan kertas putih (tabula rasa) yang dapat ditulisi apa saja yang dikehendakinya. Perwujudan kepribadian ditentukan oleh luar diri yang disebut lingkungan, dengan kiat-kiat rekayasa yang bersifat edukatif.

${ }^{19}$ Ibid. 88. 
Muhammad Mahmud menyatakan bahwa lingkungan yang mempengaruhi kepribadian terdiri atas lima faktor, yaitu geografis, historis, sosiologis, kultural, dan psikologis. ${ }^{20}$ Lingkungan geografis disebut juga lingkungan alamiah, yaitu lingkungan yang ditentukan oleh letak wilaya dan kondisi iklim. Etak wilaya seperti didaratan, pengunungan dan pesisir pantai. Kondisi iklim seperti panas, tropik, sedang dan salju. Lingkungan historis, yaitu lingkungan yang ditentukan oleh ciri suatu masa atau era dan segala perkembangan peradabannya. Dalam konteks keIndonesiaan, era orde lama, orde baru, dan era reformasi tanpak memiliki perbedaan. Masing-masing era memiliki corak dan kondisi tersendiri. Lingkungan sosiologi, yaitu lingkungan yang ditentukan oleh hubungan antara individu dalam suatu komunitas sosial. Hubungan ini selalu dikaitkan dengan tradisi, dan adat kebiasaan. Lingkungan kultural, yaitu lingkungan yang ditentukan oleh kultur masyarakat. Kultur ini meliputi cara berpikir, bertindak, ber-perasaan, dan sebagainya. Lingkungan psikologi, yaitu lingkungan yang ditentukan oleh konidisi kejiwaan, seperti kondisi rasa aman, keamanan, toleransi,dan sebagainya.

\section{Aliran Konvergensi}

Aliran konvergensi berasal dari kata konvergen, artinya bersifat menuju satu titik pertemuan. Aliran ini berpandangan bahwa corak kepribadian ditentukan oleh dasar (bakat, keturunan) dan lingkungan, keduaduanya memainkan peranan penting. Konfergensi sebagai satu aliran teori, menekankan adanya hubungan antara faktor pembawaan sejak lahir dan faktor pengalaman yang diperoleh dari lingkungan sekitarnya. Itu berarti bahwa aliran komvergensi ini, mempertemukan teori nativisme dan empirisme.

Manusia secara pribadi telah memiliki bakat masing-masing yang dibawanya sejak lahir (fitrah), yang kemudian karena pengaruh lingkungan yang sesuai dengan kebutuhan bakat tadi akan mengalami perkembangan. Akan tetapi bakat saka tanpa pengaruh lingkungan yang sesuai dengan kebutuhan perkembangan tersebut, tidak cukup, misalnya tiap anak manusia yang nermal mempunyai bakat untuk berdiri diatas kedua kakinya, akan tetapi

${ }^{20}$ Uraian Lebih Lanjut, lihat Muhammad Mahmud,'Ilm al-Nafs al-Ma'ashir fi Daw'i alIslam(Jeddah: Dar al-Syuruq, 1984), h.117-120. 
bakat sebagai kemungkinan ini tidak akan menjadi aktual (menjadi kenyataan), jika sekiranya anak manusia itu tidak hidup dalam lingkungan masyarakat manusia. Dengan begitu, hereditas tidak akan berkembang secara wajar apabila tidak diberi rangsangan dari faktor lingkungan. Sebaliknya, rangsangan lingkungan tidak akan membina kepribadian yang ideal tanpa didasari faktor hereditas. Ringkasnya, penentuan kepribadian seseorang dipengaruhi oleh kerja yang integral antara faktor internal dan eksternal.

Inti aliran konvergensi aliran ini, adalah bahwa kepribadian seseorang tidak hanya ditentukan oleh faktor warisan saja, dan tidak juga ditentukan oleh faktor lingkungan. Kepribadian seseorang akan di tentukan oleh hasil perpaduan antara kedua faktor tersebut, hasil kerjasama antara faktor- faktor yang ada pada diri seseorang, dan faktor- faktor yang diluarnya akan bermuara suatu pribadi yang ideal.

Sejalan dengan itu, Nasir Budiman menyatakan bahwa manusia dengan segala perwatakan dan ciri- ciri pertumbuhannya adalah perwujukan dua faktor, yaitu faktor warisa dan lingkungan. Kedua faktor ini mempengaruhi manusia dan berintegrasi dengannya sejak hari pertama kelahirannya sampai hari hayatnya. ${ }^{21}$

Berdasarkan uraian-uraian diatas, kelihatan bahwa konsep manusia perspektif Islam akan lebih dekat pada aliran kovergensi yang tidak mengabaikan konsep fitrah, walaupun tidak sama karena perbedaan para digmanya. Adapun kedekatannya, adalah bahwa islam menegaskan manusia memiliki fitrah dan sumber daya insani, serta bakat-bakat bawaan, meskipun semua itu masih merupakan potensi yang mengandung berbagai kemungkinan. Ditegaskan dalam hadis; yang terjemahannya: ${ }^{22}$

'Dari Abu Hurairah ra, bahwa Nabi Saw. Bersabda: setiap anak yang lahir, dilahirkan dalam keadaan fitrah, maka orang tualah yang menjadikan ia Yahudi, Nasrani atau Majusi'.(HR.Muslim).

Konsep fitrah dalam hadis diatas, dan sebagaimana pula yang telah dijelaskan bahwa, ia mengandung arti potensi dasar yang dibawa oleh setiap manusia sejak lahir.

${ }^{21}$ M. Nasir Budiman, pendidikan dalam perspektif Al-Qur'an (Cet.I; JakartaL Madani Press, 2001), h.49.

${ }^{22}$ Imam Ibn Husain Muslim bin Hajjaj Ibn Muslim al-Qusyairi al-Naisaburi,al- Jami shahi, Juz VI (Bairut: Dar al- Ma'rif, t.th.) h.530. 


\section{B. Fungsi Pendidikan Islambagi Manusia dalam hidup Dan Kehidupannya}

Fungsi pendidikan islam, tidak terlepas dari fungsinya, yakni perannya dalam memanusiakan manusia yang dituntut oleh ajaran islam. Hasan Langgulung mengemukakan bahwa fungsi pendidikan Islam harus mampu megakumulasikan tiga fungsi utama dari agama, yaitu fungsi spiritual yang berkaitan dengan aqidah dan iman, fungsi psikologi yang berkaitan dengan tinkah laku individual, termasuk nilai-nilai akhlak yang mengankat derajat manusia ke derajat yang lebih tinggi dan sempurna, serta fungsi sosial yang berkaitan dengan aturan-aturan yang menghubungkan manusia dengan manusia lain atau masyarakat, dimana masingmasing mempunya hak dan tanggung jawab untuk membentuk suatu tatanan masyarakat yang harmonis dan seimbang. ${ }^{23}$

Perumusan fungsi pendidikan islam, harus pula dikaitkan dengan tujuan penciptaan manusia, karena sebagaimana yang telah dijelaskan manuasia sebagai objek pendidikan yaitu makhluk yang dapat dididik (homo educandum), dan sebagai subyek pendidikan yaitu makhluk yang dapat mendidik (homo education). Manusia hidup hanya kebetulan dan sia-sia tanpa makna, ia diciptakan dengan membawa tujuan dan tugas hidup tertentu. Tujuan diciptakan manusia adalah hanya untuk Allah. Indikasi tugas dan fungsinya, telah disinggun dalam uraian terdahulu, yakni tugas utama adalah mengabdi (sebagai abdullah) dan fungsi utamanya sebagai wakil Allah di bumi ( khalifatullah).

Zakiah Darajat dalam menguraikan fungsi umum pendidikan islam, merumuskan tentang apa yang hendak dicapai semua kegiatan pendidikan yang meliputi seluruh aspek kemanusiaan, yakni tingkah laku, penampilan, kebiasaan dan pandangan. Kemudian sampailah pada tujuan akhirnya, yakni membentuk insan kamil dengan pola takwa. Lebih lanjut dijelaskannya bahwa fungsi sementara pendidikan islam, ialah tujuan yang akan dicapai setelah anak didik diberi sejumlah pengalaman tertentu yang direncanakan dalam suatu kurikulum pendidikan formal, dan tujuan operasional pendidikan islam adalah tujuan praktis yang akan dicapai dengan sejumlah kegiatan pendidikan tertentu. ${ }^{24}$

Fungsi pendidikan Islam dalam hidupan manusia tidak terlepas dari fungsi pendidikan nasional, sebagaimana yang diatur dalam Undang- undang Sisdiknas tahun 2003, yakni;

${ }^{23}$ Hasan Langgulung, Beberapa Pemikiran tentang pendidikan Islam (Bandung: alMa'arif,1980),h.178.

24 Disadur dari Zakiah Daradjat,ilmu Pendidikan Islam (Cat.III; Jakarta: Bumi Aksara,1996),h.30-33. 


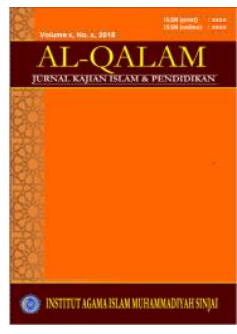

AL-QALAM

Jurnal Kajian Islam \& Pendidikan

Volume 06 No 012014

ISSN (print) : 1858-4152

ISSN (online) : -

Homepage : http://journal.iaimsinjai.ac.id/index.php/al-qalam

Pendidikan Nasional berfungsi mengembangkan kemampuan dan membentuk watak peradaban bangsa yang bermartabat dalam rangka mencerdaskan kehidupan bangsa. ${ }^{25}$

Kaitannya dengan fungsi pendidikan Nasional, dan dalam upaya pencapaian tujuan tujuan pendidikan nasionalntadi, maka pendidikan Islam dengan berfungsi membentuk manusia Indonesia yang beriman dan bertakwa terhadap Tuhan Yang Maha Esa dan sekaligus menjadi warga negara yang baik. Sebagai warga yang baik bercermin dalam kehidupan bermasyarakat, berbangsa dan bernegara. Untuk fungsi ini pula, pendidikan islam diarahkan untuk pelestarian asas-asas pembangunan nasional yang merupakan prinsip yang harus di tetapkan dan di pegang teguh dalam perencanaan dan pelaksanaan pembangunan nasional.

Dalam konteks itulah, diketahui bahwa fungsi pendidikan Islam secara totalitas untuk membangun manusia yang mampu membangun dunia dengan segala dimensinya, sesuai dengan kemitmen imannya terhadap Allah swt. Selain itu, fungsi pendidikan Islam dalam membina manusia dengan segala aspeknya, terutama menyangkut dimensi keimanan dan ketaqwaan harus benar-benar terwujud. Atas dasar itu, maka dalam pandangan penulis bahwa pendidikan islam secara fungsional harus diinternalisasikan secara institusional, institusional, dan nasional. Dengan cara seperti ini, merupakan konsekuensi penguatan komitmen iman bagi peserta didik terhadap Allah swt. Yang kemudian dimanifestasikan dalam ketaatan beribadah kepada-Nya.

Untuk lebih memperjelaskan fungsi pendidikan Islam di ere sekarang ini, dapat ditinjau dari fenomena yang muncul dalam perkembangan peradaban manusia, dengan asumsi bahwa peradaban manusia sekarang senantiasa tumbuh dan berkembang melalui pendidikan. Manusia di era ini diperhadapan dengan dilema semakin berkembang teknologi informasi. Aneka ragam informasi dapat diterima dalam sesaat sehingga wawasan manusia semakin luas. Disinilah fingsi pendidikan Islam untuk tetap mengembangkan wawasan manusia berdasarkan ajaran islam, yakni memberikan kemampuan membaca (iqra) pada peserta didik.

Perintah membaca dalam ajaran islam, bukan sekedar membaca tulisan, atau membaca mata pelajaran saja, tetapi membaca fenomena alam dan peristiwa kehidupan. Di era ini telah membaca dengan jelas berbagai fenomena yang dapat menghancurkan akhlak (moralitas), maka fungsi pendidikan islam, adalah berusaha mengiring manusia (peserta didik) agar berbudi luhur melalui

${ }^{25}$ Undang- undang Sisdiknas, Bab III, pasal 3. 


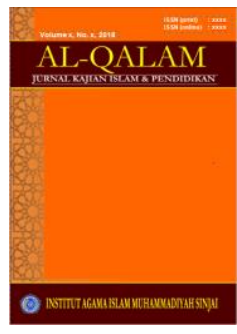

AL-QALAM

Jurmall Kajian Islam \& Pendidikan

Volume 06 No 012014

ISSN (print) : 1858-4152

ISSN (online) : -

Homepage : http://journal.iaimsinjai.ac.id/index.php/al-qalam

pendidikan informal, formal,dan non formal secara seimbang dalam bingkaian moral keislaman.

Dengan kembali merujuk pada fungsi pendidikan islam, serta kaitannya hidup dan kehidupan manusia, Maka perlu ditegaskan bahwa manusia sebagai peserta didik, harus mendapatkan pendidikan islam dengan menekankan pembinaan pada unsur materi (jasmani)-nya dan inmateril (akar dan jiwa)-nya secara konfrehensi. Pembinaan jasmaniyah menghasilkan keterampilan, pembinaan akal menghasilkan ilmu, pembinaan jiwa akan menghasilkan kesucian dan etika (moralitas) yang baik. Dengan penggabungan unsur-unsur tersebut, terciptalah makhluk dua dimensi dalam satu keseimbangan ilmu dan iman. Dengan ilmunya, ia dapat menguasai teknologi modern. Dengan imannya, ia mempergunakan teknologi tersebut secara baik sesuai ajaran islam untuk kebahagiaan hidupnya, yang orientasinnya ditujukan kepada tiga aspek yang paling utam

1. Orientasi pengetahuan Kepada Allah Yang Maha Mengetahui, yang menjadi sumbernya segala sumber ilmu pengetahuan.

2. Orientasi pengetahuan kearah kehidupan sosial manusia, dimana mu'amalah (bayn al-nas), yakni pergaulan antara sesama manusia semakin kompleks dan luas ruang lingkupnya akibat pengaruh kemajuan ilmu dan teknologi modern yang maju pesat.

3. Orientasi pengembangan kearah alam sekitar yang diciptakan Allah untuk kepentingan hidup manusia, mengandung berbagai macam kekayaan alam yang harus di gali, dikelola dan di manfaatkan oleh manusia bagi kesejahteraan hidupnya di dunia untuk mencapai kebahagiaan hidup di akhirat. $^{26}$

Orientasi pertama yang di sebut tadi, yakni pendidikan islam mengarah kepada pengetahuan pada Allah swt, implementasinya dapat dilihat dari kisah Luqman kepada anaknya yang diungkapkan oleh Al-Qur'an dengan bahasa sederhan, tapi srat dengan nilai pendidikan ketuhanan. ${ }^{27}$ Inti isi kisah Luqman tersebut, adalah bahwa hikmah yang diterimanya bersumber dari Allah swt. Sebagi mana dalam QS. Luqman (31): 12.

${ }^{26}$ M. Arifin, op.cit.,h. 112-113.

${ }^{27}$ Lihat Secara Lengkap QS. Luqman (31):12-19. 

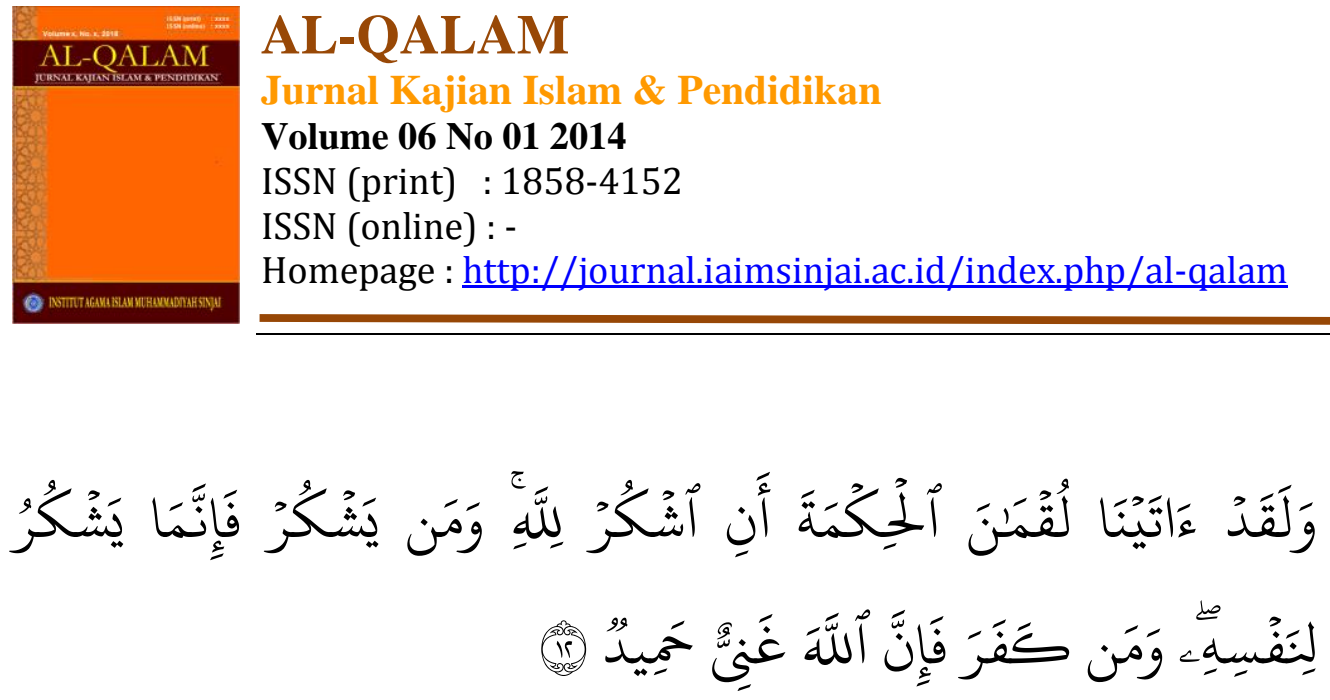

Terjemahnya :

Dan sesungguhnya telah kami berikan hikmat kepada Luqman, yaitu: "bersyukurlah kepada Allah. Dan barang siapa yang bersyukur (kepada Allah), maka sesungguhnya ia bersyukur untuk dirinya sendiri; dan barang siapa yang tidak bersyukur, maka sesungguhnya Allah Maka Kaya lagi Maka Terpuji". ${ }^{28}$

Orientasi kedua, yakni pengembangan ke arah kehidupan sosial manusia, mengindikasikan bahwa transmisi pengetahuan dalam pendidikan islam terjalin beberapa komponen didalamnya. Komponen-komponen tersebut teruta antara guru (pendidik) dan murid (peserta didik). Hal ini lebih berkembang lagi hubungan bayn al-nas, misalnya orang tua dengan guru, dan seterusnya. Orientasi pendidikan islam yang demikian, sebagai pengembangan kemampuan pada subyek didik juga yang bersumber dari pendidik. ${ }^{29}$ Dari sini dipahami dalam proses belajar mengajar, antara pendidik dan siterdidik berada pada situasi saling memperhatikan dan mempengaruhi antara satu sama lain. Interdependensi diantara mereka akan mewujudkan sosial dialogis dalam memecahkan problema bersama guna menghadapi realitas kehidupan.

Orientasi ketiga, yakni pengembangan kearah alam sekitar yang diciptakan allah untuk kepentingan hidup manusia, mengandung arti bahwa pendidikan islam adalah laksana menjalankan fungsi memberi makanan rohani pada anak (peserta didik), sagar anak dapat mendiri, kritis dan kreatis, serta memberinya latihan berbagai keterampilan yang dibutuhkan untuk mengelolah alam sekitar dengan tujuan kesejahteraan bagi umat manusia pada umumnya dalam upaya mencapai kebahagiaan dunia dan akhirat.

\section{KESIMPULAN}

\footnotetext{
${ }^{28}$ Departemen Agama RI,op. Cit., h.653.

${ }^{29}$ Lihat Imam Barnadib, Ke Arah Perspektif Baru Pendidikan (Jakarta: Proyek Dikti Dep.
} P dan K ,1988),h.41-42. 


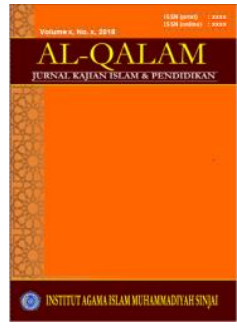

AL-QALAM

Jurnal Kajian Islam \& Pendidikan

Volume 06 No 012014

ISSN (print) : 1858-4152

ISSN (online) : -

Homepage : http://journal.iaimsinjai.ac.id/index.php/al-qalam

Berdasarkan uraian yang telah dikemukakan, maka dapat disimpulkan bahwa manusia diciptakan oleh Allah berdsarkan fitrahnya, yakni dengan naluri beragama, yaitu agama tauhid yang hanif. Dengan fitrah itu, manusia tercipta bukan di persiapkan untuk membentuk tingkah laku tersendiri, melainkan sebagai wadah atau tempat singgah fitrah islam, fitrah ketuhanan, atau fitrah rohaniyah. Kedirian dan kesendirian fitrah fisik tidak akan mampu membentuk suatu tingkah laku lahiriah, apalagi tingkah laku batiniah. Kedirian fitrah jasmani bagaikan simbol lafaz yang tidak bermakna atau bagaikan lampu yang tidak menyala.

Fungsi pendidikan Islam dalam kaitannya dengan hidup dan kehidupan manusia, dapat ditulusuri dari hakikat manusia sejak lahirnya yang memiliki fitrah, yakni potensi pembawaan yang menyebabkan dirinya harus terlibat dalam dunia pendidikan. Dalam pada itulah maka manusia homo aducandum (makhluk yang dapat didik) dan homo education (mkhluk pendidik). Dengan demikian, fungsi pendidikan Islam secara totalitas adalah, untuk membangun manusia yang mampu membangun dunia dengan segala dimensinya, sesuai dengan komitemen imannya terhadap Allah swt. Selain itu, fungsi pendidikan islam dalam membina manusia dengan segala aspeknya, terutama menyangkut dimensi keimanan dan ketaqwaan harus benr-benar berwujud. Atas dasar itu, maka dalam pandangan penulis bahwa pendidikan islam secara fungsional. Dengan cara seperti ini, merupakan konsekuensi penguatan komitmen iman bagi peserta didik terhadap Allh swt. Yang kemudian dimanifestasikan dalam ketaatan beribadah kepadaNya.

Dalam kaitan hakikat manusia dengan fitrahnya dan fungsi pendidikan Islam dalam kehidupan manusia, berimplikasi pada upaya untuk pengembangan kearah kehidupan sosial manusia, di mana mu'amalah (bayn al-nas), yakni pergaulan antara sesama manusia semakin kompleks dan luas ruang lingkupnya akibat pengaruh kemajuan ilmu dan teknologi modern yang maju pesat.

\section{DAFTAR PUSTAKA}

Ahmad, Abu. Ilmu Pendidikan. Cet. I : Jakarta Aneka Cipta, 1991.

Arifin, H.M.ilmu pendidikan Islam, Suatu Tinjauan Teoritis dan Praktis Berdasarkan

Pendekatan Interdisipliner. (Jakarta : Bumi aksara. 1997. 


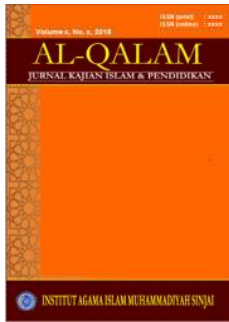

Ashfahani, al-Raghib. Mufradat Alfazh al-Qur'an. Cet. I; Bairut: Dar alSyamiyah, 1992.

Baqy, Muhammad Fu'ad 'Abd. Al-Mu'jam al-Mufahras li Alfazh al-Qur'an. Bairut: Dar al-Fikr,1988.

Barnadib, Imam. Kearah perspektif Baru pendidikan. Jakarta : proyek Dikti Dep. $\mathrm{P}$ dan $\mathrm{K}, 1988$

Budiman, M. Nasir. Pendidikan dalam Perspektif Al-Qur'a. Cet.I; JakartaL Madani Press, 2001.

Daradjat, Zakiah. Ilmu pendidikan islam. Cet.III;Jakarta: Bumi Aksara,1996.

Depertemen Agama RI, Al-Qur'an dan terjemahannya. Jakarta : Proyek

Pengadaan Kitab Suci al-qur'an, 2002

Dauli, Irsyad. Pembaharuan Kembalik pendidikan Islam. Jakarta : Karsa Utama Mandiri. 1998

Ibn Maskawaih, Tahzib al-Akhlak, diterjemahkan oleh Helmi Hidayat dengan judul Kesempulnaan Akhlak. Bandung : Mizan,1994.

Langgulung, Hasan. Beberapa pemikiran tentang pendidikan islam. Bandung : Al-ma'arif, 1980.

Muhmud, muhammad. 'Ilm al-Nafs al-ma'ashir fi Daw'i al-Islam. Jeddah: Dar al-Syuruq, 1984

Mujib, Abdul. Fitrah dan Kepribadian Islam; Sebuah Pendekatan Psikologis. Cet.I; Jakarta: Darul Falah,1999.

Naisaburi, Imam Ibn Hasain muslim bin Hajjaj Ibn muslim al-Qusyairi. AlJami Shahih, Juz VI. Bairut: Dar al-ma'arif,t,th.

Suryabrata, Sumadi. Psikologi perkembangan. Yogyakarta: Rake Press,1984. 